\title{
SHORT COMMUNICATIONS \\ DISTRIBUTION OF THE CHINESE SLEEPER PERCCOTTUS GLENII (ODONTOBUTIDAE) IN FISH COMMUNITIES OF FLOODPLAIN WATERBODIES IN THE SAMARSKAYA LUKA NATIONAL PARK (SAMARA REGION, RUSSIA)

\author{
Elena V. Kirilenko, Evgeniy V. Shemonaev \\ e-mail: kirilenkoelenav@mail.ru
} \\ Institute of Ecology of the Volga Basin of RAS, Russia \\ Received: 05.02.2017

\begin{abstract}
The article presents data on the species composition of fish in the waterbodies of the Mordovo floodplain of the Saratov Reservoir in the territory of the Samarskaya Luka National Park. The ichthyofauna of the investigated reservoirs was studied for the first time. The species structure of fish catches in five floodplain lakes and in one channel was analysed. Typological habitat conditions in waterbodies (for example, the flowage of floodplain waterbody and its connection with the Reservoir) effect the species diversity of fish. In four of the six investigated bodies of water, an alien species, the Chinese sleeper, was discovered. The biotope of the species is confined to the thickets of aquatic vegetation, regardless of the depth and place of its growth in the reservoir.
\end{abstract}

Key words: alien species, Amur sleeper, Chinese sleeper, floodplain reservoir, ichthyofauna, macrophytes, Perccottus glenii, Samarskaya Luka National Park

\section{Introduction}

Spontaneous or accidental dispersal of fish species unusual for the region (reservoir) leads to a change in biocoenotic relations (Evlanov et al., 2013; Kvach et al., 2016b.). Therefore, the biology study of invasive fish species and clarification of their role in the ecosystems of waterbodies become essential, both in scientific and practical sense.

The most evident example of such an invasion is the Chinese sleeper Perccottus glenii Dybowski, 1877, the natural range of which includes waters of the lower Amur, hence its name Amur sleeper, Primorsky Krai, north-eastern China and northern North Korea, as well as some adjacent areas (Berg, 1949). Over the past decades, actively mastering new territories, the invader covered the reservoirs of Eurasia. Outside of its native range, the sleeper currently has been recorded in the basins of Vistula, Pregolya, Neman, Daugava, Velikaya, Neva, Onega, Northern Dvina, Ob, Yenisei, Danube, Dniester, Dnieper, Don, Volga, Ural river, in the upper Amur basin (e.g., Kosco et al., 2003; Reshetnikov, 2004; Novak et al., 2008; Reshetnikov, 2009; Grabowska et al., 2011; Lukina, 2011; Zuev \& Yablokov, 2013; Kvach et al., 2016a, 2016b).

The Middle Volga basin is also included in the modern range of the Chinese sleeper (Evlanov et al., 1998; Ruchin, 2004; Kirilenko \& Shemonaev, 2011). In turn, the Volga is a first category fishery reservoir. Thus, the individual adaptive abilities of the Chinese sleeper and publications on its negative impact on the native fauna of amphibians (Reshetnikov, 2001) and fish (Elovenko, 1980; Litvinov, 1983) rise the necessity of clarification of the species' role in different types of fish communities in the Volga basin waterbodies, especially in the floodplain spawning sites. Floodplain lakes have a slow water exchange, significant seasonal fluctuations in level and a specific hydrochemical regime. A special microclimate develops around these reservoirs, which considerably affects lakeside ecosystems. Oxbow lakes, formed when a river changes its flow and a wide meander from the main stem is cut off, are not only important for the hydrographic network of the region, but also essential for maintaining biological diversity. Such a type of lake is a home for a whole complex of aquatic and semi-aquatic plants, including a number of rare and protected species (Akhtyamov et al., 2002). Ecosystems of small lakes are sensitive to climate changes in the surrounding landscape and to human economic activities (Chertoprud, 2007).

The purpose of the study: identification and distribution evaluation of the alien species of the Chinese sleeper Perccottus glenii in the fish communities of the Mordovo floodplain waterbodies of the Saratov Reservoir in the territory of the Samarskaya Luka National Park. 


\section{Material and Methods}

The research was carried out in the territory of the Samarskaya Luka National Park. Data for the study were collected from fish catches in six waterbodies (Fig.) in the Mordovo floodplain of the Saratov Reservoir (Samara Region). In the lakes Ilmen, Mostki, Soldatskoe, Pustoe and Studenaya channel samples were taken in 2011 and 2012 annually: 2 times in May, 3-4 times in the summer, once in September. At Krugloe lake, studies were conducted in 2007-2013. Samples were taken 3-4 times in May, 6-9 times in the summer, 2-3 times in autumn every year.

The species structure of fish catches in five floodplain lakes and one channel was analysed. For fish catching in the Mordovo floodplain waterbodies of the Saratov Reservoir fixed gillnets were used with a mesh of $18,35,50,70 \mathrm{~mm}, 50 \mathrm{~m}$ long, and $1.8-2.0 \mathrm{~m}$ high, and a drag net with a mesh of $5 \mathrm{~mm}$, a length of $7 \mathrm{~m}$ and a width of $1.5 \mathrm{~m}$. The gillnets were established at a depth of $1.5-5.5 \mathrm{~m}$, the drag nets were caught at a depth of up to $1.5 \mathrm{~m}$. It should be mentioned, that all the described reservoirs in this period are abundantly overgrown with macrophytes. Circumstances like this determine the specifics of work in these reservoirs. Networks were established along the edge of the vegetation or between the macrophyte thickets. In order to use a drag net, we made corridors through the thick vegetation, in which the drag net was established. All the vegetation from the enclosed area was then removed to drag the net to the shore. The method used allowing to catch such fish species as Misgurnus fossilis (Linnaeus, 1758) and Cobitis taenia (Linnaeus, 1758).

Hydrological and hydrophysical characteristics were used to assess the relationship of abiotic factors to the species structure of fish communities: depth, $\mathrm{pH}$, surface area and perimeter of the reservoir, height above sea level, degree to which biotopes are overgrown by macrophytes, flowage of floodplain waterbodies and their relationship to the reservoir, water temperature (Table 1).

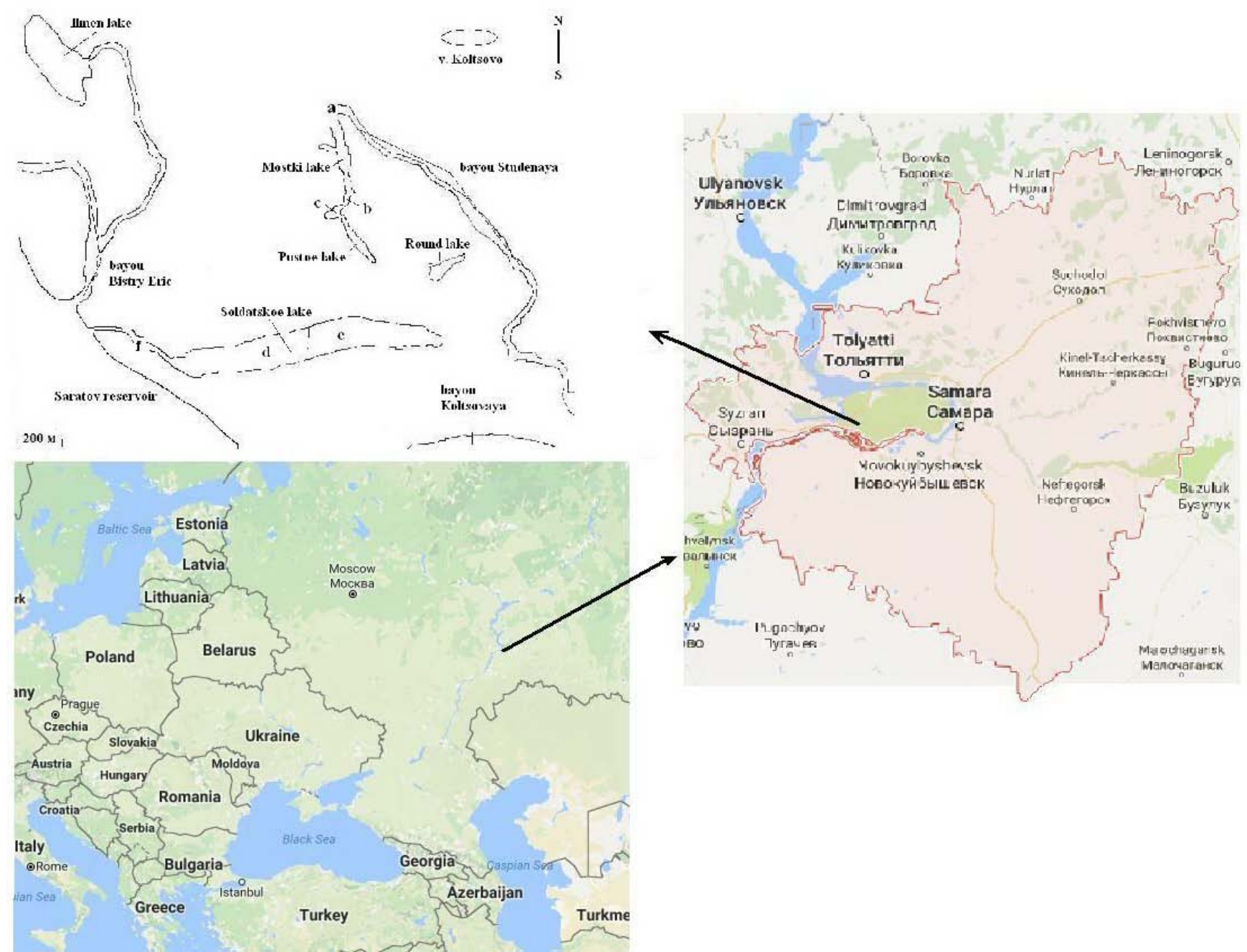

Fig. Schematic map of the Mordovo floodplain site of the Saratov Reservoir: $a$ - dam on the lake Mostki, b - marshy part of the lake Mostki, c - drying-up crossing point, d - shallow part of the lake Soldatskoe, e - deep-water part of the lake Soldatskoe, $\mathrm{f}-$ channel to the lake Soldatskoe and Saratov Reservoir. 
Table 1. Some hydrological and hydrophysical characteristics of the Mordovo floodplain waterbodies in places of sampling in June, September, 2007-2013

\begin{tabular}{|c|c|c|c|c|c|c|}
\hline \multirow{2}{*}{ Parameters } & \multicolumn{6}{|c|}{ Waterbodies } \\
\cline { 2 - 7 } & Krugloe lake & Ilmen Lake & Soldatskoe lake & Mostki lake & Pustoe lake & Studenaya channel \\
\hline $\mathrm{S}, \mathrm{m}^{2}$ & 4691 & 55546 & 125631 & 15047 & 5272 & 53721 \\
\hline $\mathrm{P}, \mathrm{m}$ & 457 & 1218 & 2467 & 1052 & 463 & 3942 \\
\hline $\mathrm{Spl}, \mathrm{m}^{2}$ & 469 & 505 & 60000 & 20 & 33 & 33942 \\
\hline $\mathrm{pH}$ & 8.57 & 9.65 & 8.78 & 9.5 & 8.37 & 8.73 \\
\hline $\mathrm{T},{ }^{\circ} \mathrm{C}$ & 27 & 26 & 27 & 29 & 20 & 25 \\
\hline $\mathrm{h}, \mathrm{m}$ & 2 & 2.5 & 3 & 2.5 & 3 & 2 \\
\hline ETSR & 0 & 0 & 1 & 0 & 0 & 1 \\
\hline EIMWR & 0 & 1 & 0 & 0 & 0 & 0 \\
\hline
\end{tabular}

Note: $\mathrm{S}$ - surface area of the reservoir in July, $\mathrm{P}$ - perimeter of the pond in July, Spl - area of overgrowth of the reservoir by macrophytes, $\mathrm{T}$ - water temperature $(1 \mathrm{~m}), \mathrm{h}$ - depth $(\mathrm{m})(\max )$, ETSR - communication with the reservoir, EIMWR - Communication with the reservoir via channels, «0»- no indication, «1»-indication. The perimeter and area of the reservoirs were calculated using the Google maps area calculator (http://3planeta.com/googlemaps/google-maps-calculator-ploschadei.html).

\section{Results and Discussion}

The Mordovo floodplain is a network of lakes, which are connected with each other and with the Saratov Reservoir by channels and river branches. Some of these waterbodies have a permanent connection with the Saratov Reservoir, while another part is connected with it exclusively in the spring high water (Fig.).

The ichthyofauna of the investigated waterbodies was studied for the first time (Table 2), and it is represented by 18 species from 8 families: sleeper Perccottus glenii, perch Perca fluviatilis, tubenose goby Proterorhinus marmoratus, Gibel carp Carassius gibelio, crucian carp Carassius carassius, common carp Cyprinus carpio, tench Tinca tinca, common bream Abramis brama, silver bream Blicca bjoerkna, roach Rutilus rutilus, common rudd Scardinius erythrophthalmus, ide Leuciscus idus, belica Leucaspius delineatus, pike Esox lucius, burbot Lota lota, black-striped pipefish Syngnathus nigrolineatus, European weather loach Misgurnus fossilis, spined loach Cobitis taenia.

Native species for the Mordovo floodplain waterbodies are: perch, roach, crucian carp, common carp, tench, common bream, silver bream, common rudd, ide, belica, pike, burbot, European weather loach and spined loach.

Fish communities alter in the studied waterbodies (Table 2). The greatest number of species is noted for Lake Soldatskoe and the Studenaya channel (13 species of fish). For Lake Pustoe representatives of the fish fauna were not found in the catches. In the lakes Krugloe, Ilmen, Soldatskoe, Mostki, an alien species was encountered - Chineese sleeper.

Under the conditions of the Mordovo floodplain, an abundant ichthyofauna composition is usual for waterbodies that have direct communication with the reservoir (13 species). In lakes, filled with water due to a difference in the position of the relief forms above sea level, the number of fish species is insignificant.

Obviously, the highest species density was formed in Lake Soldatskoe - E. lucius, R. rutilus, S. erythrophthalmus, T. tinca, C. carassius, P. fluviatilis. These fish species gravitate toward waterbodies with a large area of water mirror, sufficient depth, extended perimeter, constant connection to the Reservoir.

The community of fish species in the channel Studenaya, $S$. nigrolineatus, $P$. marmoratus, C. taenia, L. idus, has a close correlation to the area of overgrowth, waterbody perimeter and direct communication with the Reservoir. An immediate access to the Reservoir allowed blackstriped pipefish and tubenose goby to penetrate the channel, which, just like the autochthonous spined loach, prefer biotopes with abundant aquatic vegetation. The Studenaya channel is a spawning site of ide, which in early July retreats back to the Reservoir.

Perccottus glenii and Carassius gibelio appear to be indifferent to the majority of the factors under consideration. Apparently, the environmental conditions that have developed in the studied waterbodies are quite adequate for the successful existence of these species and the Chinese sleeper has occupied an ecological niche underutilised by native fish, especially in shallow enclosed waterbodies.

In the lakes Krugloe, Mostki and Soldatskoe the Chineese sleeper inhabits sections of the coastal vegetation, without leaving its boundaries. 
Table 2. Taxonomical structure and distribution of fish community in reservoirs of the Mordovo floodplain according to catches in $2007-2013$

\begin{tabular}{|c|c|c|c|c|c|c|c|}
\hline \multirow[b]{2}{*}{ Code } & \multirow[b]{2}{*}{ Taxon } & \multicolumn{6}{|c|}{ Site of Mordovo floodplain } \\
\hline & & $\begin{array}{l}\frac{0}{\frac{0}{J}} \\
\frac{0}{0} \\
\frac{0}{E} \\
\frac{1}{1}\end{array}$ & 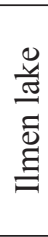 & 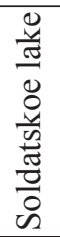 & $\begin{array}{l}\frac{0}{\pi} \\
\frac{\pi}{\pi} \\
\frac{0}{2} \\
\sum\end{array}$ & 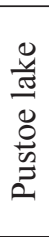 & 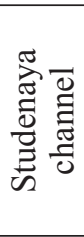 \\
\hline TEs.1 & $\begin{array}{l}\text { Class Teleostomi } \\
\text { Order Clupeiformes } \\
\text { Suborder Esocoidei } \\
\text { Family Esocidae } \\
\text { Esox lucius Linnaeus, } 1758\end{array}$ & - & + & + & + & - & + \\
\hline CRut.r & $\begin{array}{l}\text { Order Cypriniformes } \\
\text { Family Cyprinidae } \\
\text { Rutilus rutilus Linnaeus, } 1758\end{array}$ & - & - & + & - & - & + \\
\hline CL.id & Leuciscus idus Linnaeus, 1758 & - & - & + & - & - & + \\
\hline CSc.er & Scardinius erythrophthalmus Linnaeus, 1758 & - & + & + & - & - & + \\
\hline CL.del & Leucaspius delineatus Heckel, 1843 & + & - & - & - & - & - \\
\hline CT.t & Tinca tinca Linnaeus, 1758 & - & - & + & + & - & + \\
\hline CBl.bj & Blicca bjoerkna Linnaeus, 1758 & - & + & + & - & - & + \\
\hline CAb.b & Abramis brama Linnaeus, 1758 & - & + & + & + & - & + \\
\hline CC.car & Carassius carassius Linnaeus, 1758 & - & - & + & - & - & - \\
\hline CC.gib & Carassius gibelio Bloch, 1783 & + & + & + & + & - & + \\
\hline CCyp.c & Cyprinus carpio Linnaeus, 1758 & - & - & + & - & - & - \\
\hline CobC.t & $\begin{array}{l}\text { Family Cobitidae } \\
\text { Cobitis taenia Linnaeus, } 1758\end{array}$ & - & - & - & - & - & + \\
\hline CobM.f & Misgurnus fossilis Linnaeus, 1758 & + & - & - & - & - & - \\
\hline GL.1 & $\begin{array}{l}\text { Order Gadiformes } \\
\text { Family Gadidae } \\
\text { Lota lota Linnaeus, } 1758\end{array}$ & - & - & - & - & - & + \\
\hline SynS.n & $\begin{array}{l}\text { Order Syngnathiformes } \\
\text { Family Syngnathidae } \\
\text { Syngnathus nigrolineatus Eichwald, } 1831\end{array}$ & - & - & + & - & - & + \\
\hline PP.fl & $\begin{array}{l}\text { Order Perciformes } \\
\text { Family Percidae } \\
\text { Perca fluviatilis Linnaeus, } 1758\end{array}$ & - & + & + & - & - & + \\
\hline OdP.gl & $\begin{array}{l}\text { Suborder Gobioidei } \\
\text { Family Odontobutidae } \\
\text { Perccottus glenii Dyb, } 1877\end{array}$ & + & + & + & + & - & - \\
\hline GPr.m & $\begin{array}{l}\text { Family Gobiidae } \\
\text { Proterorhinus marmoratus Pall, } 1811\end{array}$ & - & - & - & - & - & + \\
\hline & Total: & 4 & 7 & 13 & 5 & 0 & 13 \\
\hline
\end{tabular}

Several researchers have noted that the usual biotope of the Chineese sleeper is a thicket of coastal shallow-water vegetation (Elovenko, 1980; Litvinov, 1983; Dgebuadze \& Skomorokhov, 2005; Pronin \& Bolonev, 2006), but in Lake Ilmen the sleeper is found in thickets of plants growing in the central part of the lake At a depth of $1.8 \mathrm{~m}$ or more, where dense vegetation spots alternate with areas of pure plant-free water. In the gill netting set up on this section of the reservoir, the species was found only in that part of the gear that was in the vegetation, the maximum depth of the catch was two me- ters. It is important to mention that in the central part of the lake, devoid of vegetation, the sleeper was not found in fishing gears, which shows its strict confinement to macrophytes, regardless of the depth and location of their growth. We can assume that the expansion of the sleeper's habitat is directly proportional to the increase of the overgrown area of the reservoir, and a change of its range depends on the intensity of large and small waterbodies overgrowth. Most likely, cleaning the reservoirs from its macrophyte vegetation will be an effective control method for this alien species. 
An exception was made by the Studenaya channel, where the sleeper was not found in catches, in spite of the appropriate biotope. In the vegetation thickets in this channel catches of drag net showed large number of perches of the size group $100-120 \mathrm{~mm}$. Since perch and sleeper share the biotope, it can be assumed that the inactive Chinese sleeper, having no protective devices, is an easily accessible prey for the predatory perch. The abundance of predators in the biotope undermines the population of the species, especially in early spring, when the water is still high and the aquatic vegetation, its covert, has not yet developed. Probably, this prevents the emergence of a self-reproducing population of the Chinese sleeper, since its predator actively hunts separate individuals of this alien species in this period. Most likely, the limiting factor in the distribution of Chinese sleeper is not simply the presence of predators (perch, pike) in the reservoir, but their abundance in spring period in the sleeper's biotope.

\section{Conclusions}

The work carried out allowed us to study for the first time the ichthyofauna of the Mordovo floodplain waterbodies in the territory of the Samarskaya Luka National Park. In four of the six investigated reservoirs, an alien species, the Chinese sleeper, was registered. Observations showed that the sleeper, found in the investigated reservoirs, prefers thickets of higher aquatic vegetation, regardless of the depth of their growth and location (coastal or pelagic).

\section{References}

Akhtyamov M.Kh., Morozova G.Yu., Boldovskiy N.V., Baburin A.A. 2002. Muravyevskiy park. Natural conditions and vegetation. Vladivostok: Far Eastern Branch of RAS. 195 p. [In Russian]

Berg L.S. 1949. Fishes of fresh water bodies in USSR and adjacent countries. In 3 vol. Moscow; Leningrad: Publisher of Academy of Sciences of USSR. 1382 p. [In Russian]

Chertoprud M.V. 2007. Bioindication of water bodies quality on the base of composition of invertebrate communities. Moscow: Moscow City Station of Young Naturalists. 24 p. [In Russian]

Dgebuadze Yu.Yu., Skomorokhov M.O. 2005. Some data on the lifestyle of Perccottus glenii Dyb. (Odontobutidae, Pisces) in lacustrine and pond populations. Proceedings of the I.Yu Zograf hydrobiological station at the lake Glubokoe 9: 212-231. [In Russian]

Elovenko V.N. 1980. About role of Chinese Sleeper in water ecosystems of the Upper Volga. In: Anthropogenic im- pacts on natural complexes and ecosystems. Volgograd. P. 57-62. [In Russian]

Evlanov I.A., Kozlovskiy S.V., Antonov P.I. 1998. Cadastre of fishes in the Samara region. Togliatti: IEVB. 222 p. [In Russian]

Evlanov I.A., Kirilenko E.V., Mineev A.K., Mineeva O.V., Mukhortova O.V., Popov A.I., Rubanova M.V., Shemonaev E.V. 2013. The influence of alien species of hydrobionts on the structural-functional organization of the Saratov reservoir ecosystem. Proceedings of Samara Scientific Centre of RAS 15(3-7): 2277-2286. [In Russian]

Grabowska J., Pietraszewski D., Przybylski M., Tarkan A.S., Marszał L., Lampart-Kałuzniacka M. 2011. Life-history traits of Amur sleeper, Perccottus glenii, in the invaded Vistula River: Early investment in reproduction but reduced growth rate. Hydrobiologia 661(1): 197-210. DOI: $10.1007 / \mathrm{s} 10750-010-0524-0$

Kirilenko E.V., Shemonaev E.V. 2011. Data about morphometry and biology of Amur Sleeper Perccottus Glenii Dybowski, 1877 for lake Krugloe of Mordovo floodplain of Saratov reservoir. Proceedings of Samara Scientific Centre of RAS 13(1): 207-210. [In Russian]

Kosco J., Lusk S., Halacka K., Luskova V. 2003. The expansion and occurrence of the Amur sleeper (Perccottus glenii) in eastern Slovakia. Folia Zoologica 52(3): 329-336.

Kvach Yu., Dykyy I., Janko K. 2016a. First record of the Chinese sleeper, Perccottus glenii Dybowski, 1877 (Actinopterygii: Odontobutidae) in the Dnieper Estuary, southern Ukraine (Black Sea drainage). BioInvasions Records 5(4): 285-290. DOI: 10.3391/ bir.2016.5.4.14

Kvach Yu., Kutsokon Yu., Stepien C.A., Marcovych M. 2016 b. Role of the invasive Chinese sleeper Perccottus glenii Dybowski 1877 (Actinopterygii: Odontobutidae) in the distribution of fish parasites in Europe: new data and a review. Biologia 71(8): 941-951. DOI: 10.1515/biolog-2016-0112

Litvinov A.G. 1983. Ecology of Chinese Sleeper (Perccottus glehni Dyb.) in the lake Baikal basin and its impact on commercial fishes. PhD thesis abstract. Saint-Petersburg. 25 p. [In Russian]

Lukina I.I. 2011. Distribution of the Amur sleeper (Perccottus glenii Dybowski, 1877) in Belarus. Russian Journal of Biological Invasions 2: 209-212. DOI: 10.1134/ S2075111711030088

Novak M., Popek W., Epler P. 2008. Range expansion of an invasive alien species, Chinese sleeper, Perccottus glenii Dybowski, 1877 (Teleostei: Odontobutidae) in the Vistula river drainage. Acta Ichthyologica et Piscatoria 38(1): 37-40. DOI: 10.3750/AIP2008.38.1.05

Pronin N.M., Bolonev E.M. 2006. On the modern geographical range of the Amur sleeper Perccottus glenii (Perciformes: Odontobutidae) in the Baikal Region, and its penetration into the ecosystem of Open Baikal. Journal of Ichthyology 46(7): 547-549. DOI: 10.1134/S0032945206070071

Reshetnikov A.N. 2001. Influence of Introduced Fish Perccottus glenii (Odontobutidae) on Amphibians in Small Waterbodies of Moscow Region. Zhurnal Obshchei Biologii 62(4): 352-361. [In Russian] 
Reshetnikov A.N. 2004. The fish Perccottus glenii: history of introduction to western regions of Eurasia. $\mathrm{Hy}$ drobiologia 522(1): 349-350. DOI: 10.1023/B:HY DR.0000030060.29433.34

Reshetnikov A.N. 2009. The current range of Amur sleeper Perccottus glenii Dybowski, 1877 (Odontobutidae, Pisces) in Eurasia. Russian Journal of Biological Invasions 1(2): 119-126. DOI: 10.1134/S2075111710020116
Ruchin A.B. 2004. Dynamics of the species diversity of Cyclostomata and fishes of Mordovia. Journal of Ichthyology 44(8): 569-574. [In Russian]

Zuev I.V., Yablokov N.O. 2013. The First Finding of Amur Sleeper Perccottus Glenii Dybowski, 1877 (Perciformes: Odontobutidae) in the Middle Yenisei Basin. Journal of Siberian Federal University. Biology 6(3): 243-245. [In Russian]

\title{
РАСПРЕДЕЛЕНИЕ РОТАНА PERCCOTTUS GLENII (ODONTOBUTIDAE) В ИХТИОСООБЩЕСТВАХ ПОЙМЕННЫХ ВОДОЕМОВ НАЦИОНАЛЬНОГО ПАРКА «САМАРСКАЯ ЛУКА» (САМАРСКАЯ ОБЛАСТЬ, РОССИЯ)
}

\author{
Е. В. Кириленко, Е. В. Шемонаев \\ Институт экологии Волжского бассейна РАН, Россия \\ e-mail:kirilenkoelenav@mail.ru
}

\begin{abstract}
В статье представлены данные о видовом составе рыб водоемов Мордовинской поймы Саратовского водохранилища на территории национального парка «Самарская Лука». Впервые установлена ихтиофауна исследуемых водоемов. Анализировали видовую структуру уловов рыб пяти пойменных озер и протоки. Типологические условия обитания в водоемах (например, проточность полойных водоемов и связь с водохранилищем) влияют на видовое разнообразие рыб. В четырех из шести исследованных водоемах обнаружен чужеродный вид - ротан. Биотоп вида приурочен к зарослям водной растительности независимо от глубины и места ее произрастания в водоеме.
\end{abstract}

Ключевые слова: Perccottus glenii, ихтиофауна, макрофиты, полойные водоемы, ротан-головешка, Самарская Лука, чужеродный вид 